The Materiality of Catholic Resistance in Sources for the English Jesuit Mission

Author: Aislinn Muller

Source: Engaging Sources: The Tradition and Future of Collecting History in the Society of Jesus (Proceedings of the Symposium held at Boston College, June 11-13, 2019)

Edited by: Cristiano Casalini, Emanuele Colombo, and Seth Meehan

ISBN: 978-1-947617-09-4

Published by: Institute of Jesuit Sources

Originally Published: March 1, 2021

https://doi.org/10.51238/ISJS.2019.21

Provided in Open Access by the Institute for Advanced Jesuit Studies at Boston College.

The Institute of Jesuit Sources, specializes in preserving, maintaining, and expanding for scholars around the world important texts and studies in Jesuit history, spirituality, and pedagogy.

Visit our website at https://jesuitsources.bc.edu 


\title{
The Materiality of Catholic Resistance in Sources for the English Jesuit Mission
}

\author{
AISLINN MULLER
}

The Society of Jesus played a critical role in preserving the material culture of English Catholicism, which came under assault following the Reformation of the 1530s. The relics, sacred objects, liturgical items, and other devotional materials that the Jesuits employed in the English mission helped to preserve the memory of England's place in the wider history of the Roman Catholic Church and sustain the links between the two. Contemporary records kept by members of the English mission in the sixteenth and seventeenth centuries likewise testify to the spiritual as well as political significance of sacred objects in England. The surviving sacred objects and the records the Jesuits kept of them helped to craft an alternative sense of history and identity for English Catholics that challenged the Protestant establishment that took hold in England after the Reformation.

As in other parts of Europe, relics and other sacred objects were criticized by religious reformers in sixteenth-century England for encouraging superstition and idolatry. ${ }^{1}$ The relic collections and devotional materials of religious houses came under particular scrutiny after King Henry VIII (r.1509-47) broke with Rome in 1534, as part of a wider project to dissolve the monasteries from 1536 to 1540 . Supposedly fraudulent relics were seized and exhibited in London, while others were burned or defaced. ${ }^{2}$ Religious houses were physically dismantled, liturgical materials were melted down and repurposed, and the nuns and monks were turned out. Apart from the reign of Mary Tudor (r.1553-58), in which Catholicism was temporarily restored from 1553 to 1558, a succession of monarchs in England passed increasingly restrictive laws to discourage and diminish Catholic forms of devotion in the sixteenth century. ${ }^{3}$ These culminated in the parliamentary legislation passed in 1571 and 1581, which in addition to making conversion to and

\footnotetext{
${ }^{1}$ Birgit Meyer and Dick Houtman have suggested that Protestant influences and suspicion of materialism contributed, until recently, to a neglect of material culture in religious studies: see their introduction to their edited volume Things: Religion and the Question of Materiality (New York: Fordham University Press, 2012), 1-24. Caroline Walker Bynum, however, has pointed out that pre-Reformation religious art and objects survived in abundance in German Protestant lands despite this suspicion. See Bynum, "Are Things 'Indifferent'? How Objects Change Our Understanding of Religious History," German History 34, no. 1 (2016): 88-112. On the ubiquity of material forms in religion, see David Morgan, ed., Religion and Material Culture: The Matter of Belief (London: Routledge, 2009), 8-10.

${ }^{2}$ Peter Marshall, Reformation England, 1480-1642 (London: Bloomsbury, 2012), 45-48.

${ }^{3}$ Marshall, Reformation England, 93-120.

https://doi.org/10.51238/ISJS.2019.21

(C) Institute of Jesuit Sources, 2021
} 
reconciliation with the Catholic Church treason, also made the use and importation of devotional objects such as rosaries, crucifixes, and relics punishable by imprisonment and forfeiture of one's property. ${ }^{4}$

The legislation was passed in reaction to a rebellion that broke out in the north of England at the end of 1569, and the subsequent excommunication and deposition of Queen Elizabeth I (r.1558-1603) by Pope Pius V (r.1566-72), who hoped the sentence would rally support for the rebels. One of the rebels' demands had been the restoration of the Catholic Mass in England; the rebellion failed, and more than six hundred of the participants were executed for treason. ${ }^{5}$ The papal excommunication of Elizabeth I contributed to the crystallization of political and social anti-Catholicism in post-Reformation England, with parliamentary legislation effectively equating Catholicism with treason and casting an air of suspicion over anyone who remained in or converted to the Roman church. ${ }^{6}$ These laws were strengthened during the reign of James I (r.1603-25), following the discovery of the Gunpowder Plot to blow up parliament and the arrest of its Catholic conspirators in 1605. New laws were passed ordering the public destruction and defacement of any sacred materials that government officials confiscated, and remained in place throughout the seventeenth century. ${ }^{7}$

The circulation of Catholic devotional materials nevertheless continued in England throughout the sixteenth and seventeenth centuries. Relics and other sacred objects were smuggled out of England for safekeeping during the dissolution of the monasteries and the iconoclastic movements of the 1530s. Some were hidden by Catholic families and brought out again for public veneration when Mary I returned England to the Catholic Church between 1553 and 1558. ${ }^{8}$ After Elizabeth I's succession and the passage of another religious settlement that separated England from the Catholic Church in 1559, reforming bishops began cracking down on church decorations and devotional objects once more. ${ }^{9}$ The parliamentary legislation threatening imprisonment and loss of property for using Catholic devotional

\footnotetext{
${ }^{4}$ Statutes of the Realm, 4 vols. (London: HM Stationery Office, 1819), 4.1:530-31, 657-58.

${ }^{5}$ On the rebellion and its causes, see Krista Kesselring, The Northern Rebellion of 1569: Faith, Politics, and Protest in Elizabethan England (Basingstoke: Palgrave Macmillan, 2007).

${ }^{6}$ For the long-term consequences of Queen Elizabeth's excommunication, see Aislinn Muller, The Excommunication of Elizabeth I: Faith, Politics, and Resistance in Post-Reformation England (Leiden: Brill, 2020).

73 Jac. I. c. 5 in Statutes of the Realm, 4.2:1080-82. On the wider implications of this legislation, see Michael Questier, "Loyalty, Religion, and State Power in Early Modern England: English Romanism and the Jacobean Oath of Allegiance," Historical Journal 40, no. 2 (1997): 311-29.

${ }^{8}$ On the afterlife of pre-Reformation devotional materials, see Alexandra Walsham, "Skeletons in the Cupboard: Relics after the English Reformation," Past \& Present 206, no. 5 (2010): 121-43; Walsham, "Recycling the Sacred: Material Culture and Cultural Memory after the English Reformation," Church History 86, no. 4 (2017): 1121-54; Eamon Duffy, The Stripping of the Altars: Traditional Religion in England, c.1400-1580, 2nd ed. (New Haven: Yale University Press, 2005), 524-64.

${ }^{9}$ Duffy, Stripping of the Altars, 565-93.
} 
objects, tied into legislation that made conversion to Catholicism treason, made safeguarding Catholic devotional objects much more dangerous. From the 1570s, priests trained at English seminaries on the continent returned to England to minister to Catholics in secret, often bringing with them sacred objects for lay Catholics who could no longer regularly access the sacraments. Jesuit missionaries likewise adopted this practice after the start of the English mission in $1580 .{ }^{10}$ Lay English Catholics traveling to and from the continent also continued to smuggle precious devotional objects and relics from the executions of captured priests and condemned Catholics out of England, often depositing them in religious houses for safekeeping, including the English Jesuit colleges in Spain, Rome, and the Netherlands.

In many ways, the uses of sacred materials in early modern England mirrored their functions in missions to other parts of the world in different time periods, as part of the sacred economy that Luke Clossey has described as integral to Jesuit missions. ${ }^{11}$ Tara Alberts, for instance, has highlighted how Jesuit missionaries attributed contact with sacred objects and images to inspiring conversions to Catholicism in early modern Southeast Asia. ${ }^{12}$ They were equally important as catechetical and liturgical tools in the Jesuit missions to South America and early modern Japan, and found similar significance in England where access to priests was limited. ${ }^{13}$ Similarly, the medicinal and protective qualities associated with sacramentals that made them popular among Catholics in England likewise made them sought after from Jesuit missionaries working in continental Europe and early modern China. ${ }^{14}$ While the legal restrictions placed on English Catholics made their

\footnotetext{
${ }^{10}$ For an overview of the Jesuit missions to Elizabethan England, see Thomas McCoog, The Society of Jesus in Ireland, Scotland, and England 1541-1588: "Our way of proceeding?" (Leiden: Brill, 1996); McCoog, The Society of Jesus in Ireland, Scotland, and England 1589-1597: Building the Faith of Saint Peter upon the King of Spain's Monarchy (Farnham: Ashgate, 2012); McCoog, The Society of Jesus in Ireland, Scotland, and England, 1598-1606: "Lest our lamp be entirely extinguished" (Leiden: Brill, 2017).

${ }^{11}$ Luke Clossey, Salvation and Globalization in the Early Jesuit Missions (Cambridge: Cambridge University Press, 2008), 216-37; see also David Morgan, "The Materiality of Sacred Economies," Material Religion 11, no. 3 (2016): 387-91. On the commodification of sacred objects more generally, see Arjun Appadurai, "Commodities and the Politics of Value," in The Social Life of Things: Commodities in Cultural Perspective, ed. Arjun Appadurai (Cambridge: Cambridge University Press, 1986), 3-63, and Patrick Geary's chapter in that volume, "Sacred Commodities: The Circulation of Medieval Relics," 169-92.

${ }^{12}$ Tara Alberts, Conflict and Conversion: Catholicism in Southeast Asia, 1500-1700 (Oxford: Oxford University Press, 2013), 147-160.

${ }^{13}$ Ana Carolina Hosne, "The 'Art of Memory' in the Jesuit Missions to Peru and China in the Late 16th Century," Material Culture Review 76, no. 1 (2012): 30-40; Antoni J. Üçerler, "The Christian Missions in Japan in the Early Modern Period," in A Companion to Early Modern Global Catholic Missions, ed. Ronnie Po-chia Hsia (Leiden: Brill, 2018), 303-43.

${ }^{14}$ Trevor Johnson, "Blood, Tears, and Xavier Water: Missionaries and Popular Religion in the Eighteenth-Century Upper Palatinate," in Popular Religion in Germany and Central Europe, ed. Robert Scribner and Trevor Johnson (Basingstoke: Macmillan, 1996), 183-202; Nadine Amsler,
} 
situation unusual in Europe, with Jesuit missionaries and seminary priests often accused by crown authorities of spreading treason, parallels have often been drawn between the English and Japanese missions in the sixteenth and seventeenth centuries because of the level of persecution Catholics faced in both countries. ${ }^{15}$

The spiritual importance of devotional objects and literature has been widely recognized by scholars of Catholicism in post-Reformation England. ${ }^{16}$ However, sources from the English Jesuit mission such as the annual letters, memoirs and correspondence of missionary priests, official histories of the mission, and surviving objects themselves also point to the ways in which both missionaries and laity employed sacred objects in expressions of subversion against successive regimes' anti-Catholic policies. This essay provides an overview of how the political dimensions of Catholic material culture were presented in surviving records from the Jesuit mission to early modern England, and how missionaries and lay Catholics engaged with these dimensions to challenge the crown.

\section{Sacred Objects as Sources for the Jesuit Missions to England}

The Jesuits' role as caretakers and producers of English Catholic material culture, and particularly of relics, has been well documented. In her studies of the collections of the former English Jesuit College of Saint-Omer, now at Stonyhurst College in the United Kingdom, Jan Graffius has demonstrated how the Jesuits and their pupils made intensive use of relics and memorials in their devotions, in ways that emphasized English Catholicism's sustained links with the unbroken history of

Jesuits and Matriarchs: Domestic Worship in Early Modern China (Seattle: University of Washington Press, 2018). Many of the thaumaturgical properties ascribed to these objects, of course, originated in the medieval church. See Caroline Walker Bynum, Christian Materiality: An Essay on Religion in Late Medieval Europe (Cambridge: MIT Press, 2011).

${ }^{15}$ Üçerler, "Christian Missions in Japan," 326-40. The Jesuit historian Daniello Bartoli (1608-85) made these comparisons in his own writings on the Society of Jesus. See, for instance, Giuseppe Boero, ed., Lettere edite ed inedite del Padre Daniello Bartoli (Bologna: Alessandro Mareggiani, 1865), 32-33.

${ }^{16}$ See, for instance, Alexandra Walsham, "Beads, Books, and Bare Ruined Choirs: Transmutations of Catholic Ritual Life in Protestant England," in Catholic Communities in Protestant States: Britain and the Netherlands c.1570-1720, ed. Ben Kaplan et al. (Manchester: Manchester University Press, 2006), 103-22; Anne Dillon, “To seek out comforts and companions of his own kind and condition': The Benedictine Rosary Confraternity and the Chapel of Cardigan House, London," in Redrawing the Map of Early Modern English Catholicism, ed. Lowell Gallagher (Toronto: University of Toronto Press, 2012), 272-308; Anne Myers, "Father John Gerard's Object Lessons: Relics and Devotional Objects in the Autobiography of a Hunted Priest," in Catholic Culture in Early Modern England, ed. Ronald Corthell et al. (Notre Dame: University of Notre Dame Press, 2007), 216-35; Robyn Malo, "Intimate Devotion: Recusant Martyrs and the Making of Relics in PostReformation England," Journal of Medieval and Early Modern Studies 44, no. 3 (2014): 531-48; Lisa McClain, "Using What's at Hand: English Catholic Reinterpretations of the Rosary, 15591642," Journal of Religious History 27, no. 2 (2003): 161-76. 
the wider Catholic Church. ${ }^{17}$ Saint-Omer was founded in 1593 by Robert Persons, one of the first Jesuits in the English mission, as a school for the sons of English Catholic families. The college housed relics spanning the history of the wider Catholic Church as well as of Catholicism in England particularly, which were often venerated together in the devotions of the college residents. A diptych constructed for the college in 1611, for example, contained relics of the Holy Family alongside relics of English saints including Alban, George, and Thomas Becket. Another reliquary that survives from Saint-Omer combines relics of royal saints from the British Isles such as Queen Margaret of Scotland, Edward the Confessor (r.104266), and Saints Oswald and Edmund. A cross reliquary, given to the college as a gift, was filled with a similar collection of relics that combined the history of the Catholic Church, English Catholicism, and the Society of Jesus: relics of the first Jesuits including Ignatius of Loyola and Francis Xavier were placed alongside relics of Thomas Becket and martyrs of the early church such as Ursula, Cecilia, and Catherine of Alexandria. Similarly, relics of English Jesuits more recently martyred, such as Edmund Campion and Robert Southwell, were placed alongside remains of early and medieval saints such as Onofrius and Augustine of Canterbury for veneration, to emphasize that England's links with the mother church remained unbroken. ${ }^{18}$

While these relic compilations helped to demonstrate England's place in the broader history of the Catholic Church, some of them also had more political connotations, especially those connected to the Stuart monarchs. As Graffius has shown, the Stuart relics kept at Saint-Omer symbolized the hopes of English Catholics that Catholicism might one day be fully restored in England. ${ }^{19}$ The college housed several relics belonging to Mary Queen of Scots (r.1542-67), for instance, including a book of hours that she used for personal devotions and bequeathed to one of her ladies in waiting shortly before her execution in 1587, and a reliquary containing part of a thorn from the crown believed to be worn by Jesus at the crucifixion. The thorn reliquary is one of the best-known surviving objects associated with Mary Queen of Scots. Formerly part of the relic collection housed at SainteChapelle in Paris, it was given to her by the French king Henri II (r.1547-59) upon the occasion of her marriage to his son, the Dauphin François. Mary brought the reliquary with her from France when she returned to Scotland in 1562, following her husband's death, and later to England when she abdicated her throne in 1567.

\footnotetext{
${ }^{17}$ Janet Graffius, "Relics and Cultures of Commemoration in the English Jesuit College of St. Omers in the Spanish Netherlands," in Jesuit Intellectual and Physical Exchange between England and Mainland Europe, c.1580-1789: "The world is our house", ed. James Kelly and Hannah Thomas (Leiden: Brill, 2019), 113-32.

${ }^{18}$ Graffius, "Cultures of Commemoration," 115-26.

19 Janet Graffius, "The Stuart Relics in the Stonyhurst Collections," Recusant History 31, no. 2 (2012): 147-69.
} 
Sometime between 1567 and 1569, she gave the reliquary over to the earl of Northumberland, who led the Northern Rebellion against Queen Elizabeth I in 1569. ${ }^{20}$ One of the rebels' demands, in addition to the restoration of the Catholic Mass in England, was the release of Mary Queen of Scots from house arrest. ${ }^{21}$ In light of the rebellion's aftermath and the subsequent papal excommunication of Elizabeth I, the Scottish queen, as Elizabeth's closest Catholic relation, became the true successor to the English crown in the eyes of the papacy and most of Catholic Europe. ${ }^{22}$ Plots to assassinate Elizabeth and replace her with the Scottish queen erupted at various points between 1570 and Mary's eventual execution in 1587, making her a continuous source of anxiety and a threat to the realm from the perspective of Elizabeth's ministers. $^{23}$

It is unclear as to why exactly Mary gave the thorn reliquary to the earl of Northumberland - possibly she feared that her English custodians might confiscate it, or it is possible that she gave it to Northumberland as a gesture of friendship and alliance. Northumberland gave the reliquary to his daughter, Elizabeth Percy, before his execution for treason in 1572. Percy remained in England and provided support for priests who came in from the continental seminaries, including the Jesuit John Gerard, whose autobiography remains a key source of information about the provenance of the thorn reliquary. ${ }^{24}$ The inscription engraved on the reliquary notes that Elizabeth gave it over to the care of the Society of Jesus, and that the gold reliquary itself was donated to preserve the thorn by Jane Wiseman, who also helped to hide missionary priests from the Elizabethan authorities in the early 1590s. Graffius notes that the reliquary was probably cared for by the Jesuits in London until the 1660s when it was brought to Saint-Omer, possibly for safekeeping during an outbreak of plague. It is remarkable that the Jesuits hid such an object in England for so long, given how dangerous it was for them to minister in England during the sixteenth and seventeenth centuries and how politically charged anything belonging to Mary Queen of Scots would have been. Immediately after Mary's execution in 1587, all of her possessions were seized and burned to prevent any witnesses from carrying them off as relics. Keeping a relic like the thorn was a statement of defiance as much as an effort to preserve the bonds between English Catholicism and the Roman church. The thorn reliquary provided direct links between the origins of Christianity, the Stuart line, and the English Catholics who

\footnotetext{
${ }^{20}$ Graffius, "Stuart Relics," 153-56.

${ }^{21}$ Kesselring, Northern Rebellion, 49-52.

${ }^{22}$ Thomas McCoog, "A View from Abroad: Continental Powers and the Succession," in Doubtful and Dangerous: The Question of the Succession in Late Elizabethan England, ed. Susan Doran and Paulina Kewes (Manchester: Manchester University Press, 2014), 257-75.

${ }^{23}$ Anne McLaren, "Gender, Religion, and Early Modern Nationalism: Elizabeth I, Mary Queen of Scots, and the Genesis of English Anti-Catholicism," American Historical Review 107, no. 3 (2002): $739-67$.

${ }^{24}$ Graffius, "Stuart Relics,” 155.
} 
cared for it at various points in its history. ${ }^{25}$ By emphasizing these links, however, the reliquary also acted as a challenge to the legitimacy of Elizabeth's rule.

The Jesuits, of course, were not unique in their care of relics significant to English Catholic history. James Kelly has highlighted how communities of English women religious in early modern Europe played a central role in the acquisition and preservation of contemporary English Catholic relics and those dating back to early Christianity. ${ }^{26}$ English Benedictines in Dunkirk, for instance, kept a reliquary crucifix that had supposedly belonged to an abbot of Fountains Abbey in Yorkshire before the dissolution of the 1530s, while the Bridgettines possessed a vial believed to contain the holy blood of Christ, which had previously been held at the Cistercian abbey of Hailes in Gloucestershire. Houses of women religious also preserved the remains of English Catholics executed for their faith, which were often brought to them by postulants who had carried them out of England. ${ }^{27}$ In so doing, the English religious orders established in Europe after the Reformation participated in a cult of veneration practiced and encouraged widely by the Tridentine church, while at the same time fostering a distinct English Catholic history that could be invoked if ever the Roman Catholic Church was fully restored in their homeland.

\section{Sacred Objects in the Written Records of the English Jesuit Mission}

Surviving records speak to the pivotal contribution that devotional materials played in the Jesuit missions to England as well as in collegiate life on the continent. Annual letters for England, missionary correspondence, and reports from the English agents tasked with apprehending the priests offer glimpses of how devotional objects were distributed, used in prayer, helped to heal the sick, and deployed to avert natural disasters, among other things. ${ }^{28}$ Written sources also illuminate how sacred materials were sometimes used in more pointed acts of resistance against the Elizabethan and Stuart governments. Lay Catholics sometimes wore sacred objects publicly in defiance of parliamentary statutes, priests carried them to the scaffold

\footnotetext{
${ }^{25}$ Graffius, "Stuart Relics," 150, 155.

${ }^{26}$ James Kelly, "Creating an English Catholic Identity: Relics, Martyrs, and English Women Religious in Counter-Reformation Europe," in Early Modern English Catholicism: Identity, Memory, and Counter-Reformation, ed. James Kelly and Susan Royal (Leiden: Brill, 2017), 41-59. Scholarship on English women religious has undergone something of a renaissance, notably thanks to the efforts of Caroline Bowden and the research network, "History of Women Religious of Britain and Ireland." See, for instance, Caroline Bowden, English Convents in Exile, 1600-1800, 6 vols. (London: Pickering \& Chatto, 2012-13) and https://historyofwomenreligious.org/women-religiousbibliography/ (accessed August 12, 2020).

${ }^{27}$ Kelly, "Relics, Martyrs, and English Women Religious," 53.

${ }^{28}$ Thomas McCoog, English and Welsh Jesuits, 1555-1650, 2 vols. (Rome: Institutum Historicum Societatis Iesu, 1992), 1:xxx-xxxi.
} 
as spiritual comforts, and the remains of executed Catholics were collected and preserved despite government efforts to quell the practice.

Memoirs such as the autobiography of the English Jesuit John Gerard, along with published works such as the Spanish Jesuit Pedro de Ribadeneyra's Historia ecclesiastica del scisma de Inglaterra (1588) and Henry More's Historia Anglicana Societatis Iesu (1660), likewise provide insight into how sacred objects conveyed both spiritual comfort and expressions of dissent from the crown's anti-Catholic policies in the sixteenth and seventeenth centuries. These three Jesuits experienced the English mission in different ways, and their writings about the mission reflected these varied perspectives. Gerard was from an English Catholic gentry family based in the north of England. He was educated at the English College in Douai and Rheims as a teenager and ordained a priest by papal dispensation in 1588 . He was admitted to the Jesuits in the same year and sent on the English mission shortly afterward. Gerard worked in England until 1606, when he fled following the capture and execution of several of his friends and colleagues for involvement in the Gunpowder Plot. ${ }^{29}$ More studied at Saint-Omer as a child before joining the Society in 1622. He worked in the London district of the English mission for most of his career, which spanned the civil wars from 1642 to 1651 and the eventual restoration of the monarchy in 1660, and served as superior and vice-provincial of the English province. ${ }^{30}$ Ribadeneyra, on the other hand, visited England only briefly in 1558, shortly before the death of Queen Mary and the accession of Elizabeth I. Although Ribadeneyra spent little time in England, he became a close friend and correspondent of prominent members of the English Catholic community in Europe, including the Jesuit Robert Persons. ${ }^{31}$

Their accounts of England were published for different purposes: editors of Gerard's memoir have posited that he wrote it primarily for fellow Jesuits and novices, but certain features of the prose suggest that he may have anticipated a wider audience for his autobiography. ${ }^{32}$ Gerard was careful, for instance, to leave out the names of Catholic families he interacted with during his mission - in general, only those who were already dead at the time of writing are mentioned by name. This suggests that Gerard took precautions in case his memoir ever found its way into the hands of government officials. Ribadeneyra's Historia was written primarily

\footnotetext{
${ }^{29}$ Thomas McCoog, "Gerard, John," Oxford Dictionary of National Biography (Oxford: Oxford University Press, 2004); https://doi.org/10.1093/ref:odnb/10556 (accessed August 25, 2020).

${ }^{30}$ Thomas McCoog, "More, Henry (c.1587-1661)," Oxford Dictionary of National Biography (Oxford: Oxford University Press, 2004); http://www.oxforddnb.com/view/article/19180 (accessed August 12, 2020).

${ }^{31}$ Spencer Weinreich, "England in the Margin: Providence and Historiography in Pedro de Ribadeneyra's Historia ecclesiastica del scisma del reyno de Inglaterra," in Kelly and Thomas, Jesuit Exchange, 263-64.

${ }^{32}$ Philip Caraman, preface to John Gerard, Autobiography of an Elizabethan (London: Longmans, Green, \& Co., 1951).
} 
for a Spanish audience as a call to arms for the Catholic Church in the context of a looming war between Spain and England in 1588. It became a widely popular account of the Reformation in England, with multiple editions and translations printed in Europe throughout the seventeenth and eighteenth centuries. ${ }^{33}$ Although the Jesuits figure prominently, the text is broad in its coverage of political figures and events. More, on the other hand, wrote his history of the English province at the request of the English provincial and the Jesuit superior general, and his account is more tightly focused on the individual experiences of Jesuit missionaries. ${ }^{34}$ Despite their different purposes, all of these histories employed narratives of sacred objects in ways that speak to the political as well as spiritual uses of these objects in the Jesuit mission.

The various instructions that were available for missionary priests, however, sometimes conflicted as to how sacred objects should be used in their ministry, and indeed whether they should be used at all. When the English mission was approved in 1580, the Jesuit superior general Everard Mercurian (in office 1573-80) gave the missionaries specific guidance on sacred objects. Initially, the general prohibited Jesuits from taking sacred objects such as the agnus dei (wax pendants blessed by the pope), blessed grains of incense (which were often used in rosary beads and portable altars), or any other objects on the mission that had been proscribed by the English government. ${ }^{35}$ The general imposed this rule for the priests' safety, as carrying devotional materials increased their chances of being recognized and captured, but it conflicted with the practices of seminary priests who had trained at the English College in Douai and had been working in England from 1574, who had been smuggling sacred objects to English Catholics. ${ }^{36}$ The priest Jonas Meredith, for instance, was imprisoned in London after he was found with several sets of rosary beads, a painted crucifix, and agni dei, while the seminary priest $\mathrm{Cu}$ thbert Mayne had given agnus dei pendants to the Catholic families he ministered to in Cornwall before he was captured in $1577 .{ }^{37}$

The Jesuit general's instructions also clashed with rulings on sacred objects that had been issued by Pope Gregory XIII (r.1572-85). In 1578, the pope had issued a decree that granted plenary indulgences to anyone who wore blessed grains,

\footnotetext{
${ }^{33}$ Pedro de Ribadeneyra, Ecclesiastical History of the Schism of the Kingdom of England, trans. Spencer Weinreich (Leiden: Brill, 2017); Weinreich, "England in the Margin," 273-76; see also Freddy Cristóbal Dominguez, "We Must Fight with Paper and Pens: Spanish Elizabethan Polemics, 1585-1598" (PhD diss., Princeton University, 2011).

${ }^{34}$ McCoog, "More, Henry."

${ }^{35}$ Victor Houliston, Ginevra Crosignani, and Thomas McCoog, eds., The Unpublished Correspondence and Papers of Robert Persons, S.J. (1546-1610) (Toronto: Pontifical Institute of Medieval Studies, 2017), 1:83.

${ }^{36} \mathrm{McCoog}$, Society of Jesus 1541-1588, 129-77.

${ }^{37}$ The National Archives (TNA) PC 2/11 fol. 225; British Library (BL) Lansdowne MS 25/30 fol. 63.
} 
rosaries, crucifixes, and medals, or used them in prayer. The indulgences also applied to anyone who prayed for the pope, the Catholic Church, or the conversion of England, Scotland, and Ireland. The decree had been issued at the request of the Jesuit rector of the English College at Rome, Alfonso Agazzari, and it applied to anyone who lived outside the Italian peninsula. ${ }^{38}$ Similar indulgences were granted periodically by successive popes, including Gregory XV (r.1621-23) in 1622 and Urban VIII (r.1623-44) in 1626. ${ }^{39}$ The disparity between Mercurian's instructions and the indulgences obtained by Agazzari point to the difficulties in balancing the missionaries' safety with the spiritual needs of lay Catholics in England. The plenary indulgences attached to sacred objects made them particularly appealing to English Catholics, who had infrequent access to priests and could not regularly undergo sacraments such as reconciliation and absolution from sins. ${ }^{40}$ When indulgences were attached to them, sacred objects worn and used in prayer could serve as devotional aids after missionaries had moved on. The decrees on indulgences also further complicated English Catholics' relationships with the church in Rome and the Protestant regime under which they lived: praying for the pope and the conversion of England would have been interpreted in a sinister manner by some Protestant authorities as evidence of Catholics' divided allegiances. ${ }^{41}$ Granting indulgences to anyone who prayed for the papacy and England's conversion essentially politicized certain forms of prayer, given that English Catholics became more reliant on devotional aids and personal prayer to practice their faith in the absence of regular access to priests.

The English leadership of the missions also recognized the importance of sacred objects in proselytization and conversion. Cases of conscience compiled by William Allen and Persons offered priests advice on various questions they would face from lay Catholics while working in the English missions, including on the use of devotional materials. The second case in their advice manual addressed whether priests could in good conscience "carry into England [...] and give to others [...] things which [were] prohibited under pain of death and [were] not by themselves necessary to the practice of the Catholic faith," listing the agnus dei pendants, blessed medals, and grains of incense as examples. Allen and Persons ruled that this was permissible, as long as the priests only gave such objects to those who asked

\footnotetext{
${ }^{38}$ Thomas Knox, The First and Second Diaries of the English College, Douay, and an Appendix of the Unpublished Documents (London: D. Nutt, 1878), 366-67.

39 TNA SP 14/128 fol. 7; Henry Foley, Records of the English Province of the Society of Jesus, 7 vols. (London: Burns \& Oates, 1877-83), 6:537.

${ }^{40}$ Alexandra Walsham, "Translating Trent? English Catholicism and the Counter-Reformation," Historical Research 78, no. 201 (2005): 288-310.

${ }^{41}$ For the evolution of prayer in missionary contexts, see Eamon Duffy, "Praying the Counter-Reformation," in Kelly and Royal, Early Modern English Catholicism, 206-25.
} 
for them. ${ }^{42}$ The resolution of this case explained that these objects were "most useful, because they turn people's minds towards the Apostolic See," that the spiritual benefits that sacred objects afforded could assist in persuading people to convert to Catholicism. ${ }^{43}$

The first two Jesuits in the English mission, Edmund Campion and Persons, seem to have deferred to the papal decrees rather than the instructions of the Jesuit superior general on the distribution and use of sacred objects. When Persons was working in London in the summer of 1581, government officials found a store of blessed beads, medals, crucifixes, and sacred images in the house where he had been hiding, which he had apparently brought on the mission to distribute. ${ }^{44} \mathrm{Cam}$ pion is thought to have worn an agnus dei given to him by Pope Gregory XIII before he was captured in the same year. ${ }^{45}$ After Campion and Persons, subsequent groups of Jesuits sent into England and Wales were not proscribed from bringing in devotional objects, and the papal faculties that these missionaries received upheld that praying over sacramentals could be substituted for hearing the Mass, given the dangerous circumstances in which English Catholics lived. In 1583, for instance, the instructions of Gregory XIII for the Jesuits Ralph Bickley and Thomas Hemerford granted that praying over blessed beads could be substituted for hearing the Mass in cases of necessity, and also granted the possessor of the beads a plenary indulgence. ${ }^{46}$ Pope Sixtus V (r.1585-90) issued a similar faculty allowing Jesuit missionaries to impart an apostolic blessing to Catholics in England who prayed the rosary when they could not access the Mass. ${ }^{47}$

The autobiography of Gerard offers a rich account of how sacred objects facilitated Catholic devotions under the repressive conditions imposed by the Elizabethan regime. Anne Meyers has assessed how the objects in Gerard's memoirs helped to illuminate the survival of English Catholic heritage and the preservation of English Catholic identities in Elizabethan England. ${ }^{48}$ Gerard took great care to emphasize that sacred objects were always treated with respect in the mission. During his visit to the Drury family near Bury St Edmunds, for instance, Gerard observed that "a number of things in the house needed attention," including the altar

\footnotetext{
${ }^{42}$ Peter Holmes, Elizabethan Casuistry (London: Catholic Record Society, 1981), 66-67.

${ }^{43}$ Holmes, Elizabethan Casuistry, 67.

${ }^{44}$ Foley, Records of the English Province, 4:346.

${ }^{45}$ Maya Corry, Deborah Howard, and Mary Laven, Madonnas and Miracles: The Holy Home in Renaissance Italy (Cambridge: Fitzwilliam Museum, 2017), 124. On Campion, see Gerard Kilroy, Edmund Campion: A Scholarly Life (Farnham: Ashgate, 2015).

${ }^{46}$ Foley, Records of the English Province, 6:100.

${ }^{47}$ Foley, Records of the English Province, 6:112. On the importance of indulgences attached to sacred objects, see Elizabeth Tingle, Indulgences after Luther: Pardons in Counter-Reformation France, 1520-1720 (London: Routledge, 2015), 135-54.

${ }^{48}$ Meyers, "Father John Gerard's Object Lessons," 217-21.
} 
furnishings, which he noted were "old and worn and anything but helpful to devotion." Gerard described how he "brought out some fine vestments, which were a gift to me, and in this way encouraged the widow [of the house] to make others like them" so that the Mass could be celebrated properly. ${ }^{49}$ Thus, by providing an example of good liturgical vestments, Gerard encouraged the wider production of materials appropriate for use in the Mass. The proliferation of such materials also affirms Gerard's success in proselytizing. In his memoir, Gerard recalls how when he first arrived in England he "used to take round with [him his] own Mass equipment" because his hosts "could seldom provide the essentials for Mass." After a few years of working in England, however, Gerard noted that he "would find vestments and everything else laid out ready" in nearly every house he visited. ${ }^{50}$ The increased availability of liturgical materials attests both to Gerard's success in correcting lapses in devotion and encouraging the production of materials necessary for worship.

Gerard's autobiography also stressed the efforts of both missionaries and lay Catholics to correct idolatry and abuse of sacred materials. An anecdote he included about the Jesuit Edward Oldcorne, who traveled to England with Gerard in 1588, described how Oldcorne, when visiting the house of a Catholic friend in London, was "unable to endure the sight" of a windowpane painted with an image of Mars and Venus. Oldcorne smashed the image with his fist, and "told his friend how unseemly it was to let such things stand." ${ }^{11}$ Gerard commented that this incident was "typical of his zeal for honor and truth." ${ }^{2}$ In another story, Gerard described the holy shrine of St Winifred's Well in Wales, where large red-colored stones, said to be stained with the blood of the saint, remained lodged in the bottom of the well. Gerard noted that local Catholics tried to prevent pilgrims from disturbing the stones or breaking off pieces of them to take away. ${ }^{53}$ Here again, Gerard took pains to illustrate the care with which potential relics and contact-relics were handled by Catholics in England and Wales. These stories reflected the wider debates between Catholics and Protestants about the merits of images and relics, as well as Catholic attitudes toward these materials after the Council of Trent (154563).$^{54}$ They highlighted the missionaries' zeal in correcting any practices that hinted at idolatry, and may have served to defend the Jesuits from some of the criticisms they received from Protestant polemical writers in England, who often accused the

\footnotetext{
${ }^{49}$ Gerard, Autobiography, 24.

${ }^{50}$ Gerard, Autobiography, 40.

${ }^{51}$ Gerard, Autobiography, 10.

${ }^{52}$ Gerard, Autobiography, 10.

${ }^{53}$ Gerard, Autobiography, 46. See Alexandra Walsham, "Holywell: Contesting Sacred Space in Post-Reformation Wales," in Sacred Space in Early Modern Europe, ed. Will Coster and Andrew Spicer (Cambridge: Cambridge University Press, 2005), 209-36.

${ }^{54}$ John O'Malley, Trent: What Happened at the Council (Cambridge, MA: Harvard University Press, 2000), 243-45.
} 
order of using "superstitious idols," "popish trash," and "trumperies" to attract converts to Catholicism. ${ }^{55}$

The annual letters are another key source for studying the role of sacred materials in the English mission in the late sixteenth and seventeenth centuries, and reinforced the importance of sacred objects in persuading people to convert or consider converting to Roman Catholicism. ${ }^{56}$ A report of the mission's London district, for instance, listed a law apprentice named John Jackson among its successful conversions, who attributed his conversion in part to receiving a gift of a rosary and psalter from a woman living in the house where he was apprenticed in London. ${ }^{57} \mathrm{~A}$ report from the Lancashire mission for 1655 described how one of the Jesuits working there cured a Protestant girl of demonic possession by teaching her the doctrines of Roman Catholicism and giving her some holy water that had been consecrated with a relic of Ignatius. The experience allegedly inspired in the girl "a grace of singular piety" and prompted her conversion. ${ }^{58}$ In some cases, Jesuits who participated in the English mission attributed their own conversions to interactions with sacred objects. The Jesuit Thomas Jenison recalled his conversion at the age of ten following a visit to a Catholic chapel in 1653, where he was inspired to convert after beholding the altar and several sacred images. Francis Williams, who was admitted to the Jesuits in 1660 , attributed his conversion to visiting a convent in Dunkirk, where he observed nuns reciting the rosary before a statue of the Virgin Mary. 59

The demand for sacred objects that could be used in private devotions seems to have superseded the concerns of the Jesuit superior general that carrying such objects would increase the risk of missionaries being captured and executed. Indeed, one of the reasons we know so much about the Jesuits' involvement in distributing sacred objects to English Catholics is because quite a few of them were caught: government correspondence records numerous incidents in which Jesuit priests were identified and arrested by the devotional materials they carried with them, as do the annual letters compiled for the English mission. ${ }^{60}$ The Jesuit Thomas Laithwaite, for instance, was apprehended in Plymouth in 1604 with several

\footnotetext{
${ }^{55}$ Alexandra Walsham, "The Pope's Merchandise and the Jesuits' Trumpery: Catholic Relics and Protestant Polemic in Post-Reformation England," in Religion, the Supernatural, and Visual Culture in Early Modern Europe, ed. Jennifer Spinks and Dagmar Eichberger (Leiden: Brill, 2015), 370409.

${ }^{56}$ Conversion narratives tended to follow particular patterns in the annual letters. See Ananya Chakravarti, "In the Language of the Land: Conversion in Jesuit Public Letters from Brazil and India," Journal of Early Modern History 17, no. 5 (2013): 505-24.

${ }^{57}$ Foley, Records of the English Province, 1:191-92.

${ }^{58}$ Foley, Records of the English Province, 2:21.

${ }^{59}$ Foley, Records of the English Province, 5:411-12.

${ }^{60}$ See, for instance, Calendar of the Manuscripts of the Most Honourable Marquis of Salisbury, Preserved at Hatfield House, 18 vols. (London: HM Stationery Office, 1883-1940), 4:564-65, 7:484, 11:119.
} 
agnus dei pendants, while the Jesuit lay brother John Jenkyn was also arrested there in 1633 with several crucifixes, agni dei, relics, rosaries, and sacred images. ${ }^{61}$

While the reports that Jesuit missionaries delivered from the mission outlined the spiritual benefits of sacred objects, the legislation passed by the Tudor and Stuart parliaments inherently charged their use with political significance. Because sacred objects had been outlawed by the government, their continued use inescapably became an act of defiance, though the degree of course varied depending on the situation and circumstances. The public spectacle of trials and executions, for instance, afforded many opportunities for expressing resistance to the official religious policies and treason laws, for the condemned as well as for the spectators. ${ }^{62}$ The annual letter written for the English College at Rome in 1581 described how witnesses at the execution of the priests Luke Kirby and John Shert (both former students of the college) returned to the place where their remains had been buried at nightfall, disinterred them, and smuggled them back to the college to be preserved as relics. ${ }^{63}$ Similarly, the annual letter of the college for 1583 described how a crowd present at the execution of the priest William Hart swarmed the scaffold after he had been hanged to prevent the executioners from disemboweling and quartering his body, and to collect fragments of Hart's clothing and flesh to keep as relics. ${ }^{64}$ When Anne Line was executed for harboring Jesuits in London in 1601, the countess of Arundel arranged for Line's body to be dug up from the common grave where it had been interred and taken to her house for proper burial. Henry Garnett, one of the Jesuits that Line had helped, sent one of his assistants to her execution to obtain fragments of her clothing for relics. ${ }^{65}$

In the works of More and Ribadeneyra, the public spectacle of trials and executions similarly afforded both the condemned and spectators opportunities for expressing resistance to the English government's anti-Catholic policies. When discussing English Catholics' reverence for the remains of executed priests, Ribadeneyra observed that "in England, countless Catholics go in pilgrimage to

\footnotetext{
${ }^{61}$ Foley, Records of the English Province, 4:632, 666-67.

${ }^{62}$ Clodagh Tait offers a useful model for how public executions offered opportunities to express resistance in early modern Ireland. See Tait, "Riots, Rescues, and 'Grene Bowes': Catholics and Protest in Ireland, 1570-1640," in Insular Christianity: Alternative Models of the Church in Britain and Ireland, c.1570-c.1700, ed. Robert Armstrong and Tadhg Ó hAnnracháin (Manchester: Manchester University Press, 2013), 67-87; Tait, "Relics and the Past: The Material Culture of Martyrdom in Early Modern and Modern Ireland," in Plantation Ireland: Settlement and Material Culture, c.1550-c.1700, ed. James Lyttleton and Colin Rynne (Dublin: Four Courts Press, 2009), 207-12. See also Peter Lake and Michael Quester, "Agency, Appropriation, and Rhetoric under the Gallows: Puritans, Romanists, and the State in Early Modern England," Past and Present 153 (1996): 64-107.

${ }^{63}$ Foley, Records of the English Province, 6:86.

${ }^{64}$ Foley, Records of the English Province, 6:106.

${ }^{65}$ Christine Kelly, "Line, Anne [St Anne Line]," Oxford Dictionary of National Biography (Oxford: Oxford University Press, 2009); http://doi.org/10.1093/ref:odnb/69035 (accessed August 12, 2020); Foley, Records of the English Province, 7:1366.
} 
wherever their heads and quarters are hung, as though coming to guard them, or to ask whose heads and bodies they are." He noted the careful way in which such pilgrims inquired after the remains displayed at London's city gates, asking questions such as "what traitors were they, whose heads are raised above the rest?" to avoid suspicion while offering surreptitious prayers of devotion. ${ }^{66}$ Ribadeneyra mused that "their enemies do them a greater good through the tortures and cruel deaths they inflict than all their friends and all the princes of the world could have done them," implying that the executions had reinvigorated devotion to the cult of relics among English Catholics while highlighting their boldness in revering the remains displayed in public. ${ }^{67}$

The story of Alexander Briant's trial and execution, which appears in both More and Ribadeneyra's histories of England and the Jesuit mission, pointed to some of the ways in which condemned Catholics persisted in quiet defiance of the Elizabethan regime. Briant, who assisted Campion and Persons in the first Jesuit mission and was admitted to the Society shortly before his execution for treason in 1581, carried a wooden crucifix to his trial that he had made while in prison, and held it before the crowd at his execution on December $1,1581 .{ }^{68}$ Ribadeneyra described how, when Briant was brought to his sentencing, "he found a way to make a little wooden crucifix, which he carried openly, and to cut himself a tonsure, to show the heretics he prized his holy orders and his faith." ${ }^{\text {"99 }}$ More wrote of Briant that he "took care to have his tonsure uncovered to show openly how much store he set by his ordination" and that "he also made a little cross out of wood, with an image of Christ modelled in charcoal affixed to it."70 Both More and Ribadeneyra emphasized Briant's public display of the crucifix, acknowledging this action as both a statement of faith and a demonstration of subversion. Although Briant fashioned the crucifix to provide spiritual comfort through his ordeal, carrying it publicly also functioned as a sign of resistance to the Elizabethan regime, one that spectators at his trial and execution would have recognized as defiance of the parliamentary statute passed in 1571. Briant's care with his tonsure served a similar purpose, proclaiming his ordination as a Catholic priest to all who saw him.

More's recording of the death of the priest Mark Barkworth, who was executed in 1601, noted similar uses of materials at hand. More described how Barkworth "made the sign of the cross on himself, the wood to which he was to be tied, and the rope itself. He then kissed each object in turn and recited one of the

${ }^{66}$ Ribadeneyra, Ecclesiastical History, 485-86.

${ }^{67}$ Ribadeneyra, Ecclesiastical History, 485-86.

${ }^{68}$ Foley, Records of the English Province, 3:700.

${ }^{69}$ Ribadeneyra, Ecclesiastical History, 469.

${ }^{70}$ Henry More, The Elizabethan Jesuits: Historia missionis Anglicanae Societatis Iesu, trans. Francis Edwards (London: Phillimore, 1981), 132-33. 
joyful psalms." ${ }^{\prime 71}$ In More's narration, Barkworth, by blessing the materials with which he was to be killed, participated actively in the process by which his body would be transformed into hallowed remains after his death. In so doing, Barkworth openly defied the statutes against consecrated objects and might have encouraged sympathetic spectators to collect these materials when he expired.

Gerard's autobiography also testifies to his success in convincing Catholic families to assume a certain amount of risk by keeping prohibited relics and sacred objects in their homes. In one passage, Gerard detailed how a silver reliquary containing a piece of the skull of Thomas Becket of Canterbury came into his possession briefly. Although the reliquary was old and had lost some of the gemstones with which it had been adorned, the gentleman who gave the reliquary to Gerard had recently had it "repaired and finely ornamented."72 Impressed with his efforts, Gerard obtained permission from the superior of the mission to return the reliquary to the unnamed gentleman to "keep it in trust for the Society." 73 Here, Gerard noted how the anonymous layman was rewarded for his reverence of a precious relic by being allowed to keep it on behalf of the Society instead of having it smuggled out of the country for safekeeping. Yet this story also provides us with another example of defiance, in this case of multiple Tudor regimes that sought to remove and destroy relics after England's break with Rome in the 1530s. The shrine of Becket at Canterbury had been targeted particularly by Henry VIII during the Reformation. ${ }^{74}$ In 1538, the king issued a royal proclamation ordering that Becket no longer be venerated as a saint, calling him "a rebel and a traitor to his prince" for resisting his predecessor, Henry II's (r.1154-89) attempts to assert royal authority over the church. ${ }^{75}$ Restoring and redecorating a relic of Becket in this context, especially in light of Elizabeth I's own conflict with the papacy as a result of her excommunication, would have served as a pointed challenge to the queen's legitimacy and the authority of her government.

In Gerard's recollections, sacred materials serve multiple narrative purposes. The production of liturgical materials and reliquaries as he described them speaks to the strength of English Catholicism and emphasizes its compatibility with reforms of Catholic worship after the conclusion of the Council of Trent, particularly with respect to the veneration of relics and sacramentals. Yet these stories also attest to an increase in the number of Catholics willing to defy the Elizabethan regime's statutes against devotional materials by engaging in their production,

\footnotetext{
${ }^{71}$ More, Elizabethan Jesuits, 324.

${ }^{72}$ Gerard, Autobiography, 49-50.

${ }^{73}$ Gerard, Autobiography, 49-50.

${ }^{74}$ Alec Ryrie, The Age of Reformation: The Tudor and Stewart Realms, 1485-1603 (Harlow: Longman, 2009), 134.

${ }^{75}$ A Proclamation Removing Thomas Becket from the Calendar (London: Thomas Berthelet, 1538), 3.
} 
facilitating their preservation, and continuing to use them personally. By encouraging these activities, Gerard was encouraging the families that hosted him to risk imprisonment and even charges of treason if they were discovered. That he was so successful in persuading English Catholics to assume these risks also indicates a willingness among the laity to accept the new political connotations of Catholic devotional materials, and in so doing, to express doubts about the legitimacy of the Elizabethan government.

Gerard also recounted moments in which the sacred materials he relied upon to carry out his ministry took on more overtly subversive connotations. Recalling his imprisonment as a youth in London in 1584, Gerard described how he concealed books and altar plate in his prison cell, so that a priest in the neighboring cell could celebrate Mass every morning. During his later imprisonment in the Tower of London in the 1590s, Gerard fashioned crucifixes and rosaries from the peelings of oranges that he obtained from the warden, and sent them to his fellow prisoners as gifts with messages written in invisible ink derived from the juice. ${ }^{76}$ Gerard narrated a similar story about the Catholic widow Jane Wiseman, who as noted previously, supposedly commissioned the reliquary for Mary Queen of Scots' fragment of the crown of thorns. Wiseman had been arrested for harboring priests in 1598 and was sentenced to be crushed to death for refusing to plead at her trial. ${ }^{77}$ The crown commuted her sentence to life imprisonment, but according to Gerard, Wiseman's narrow escape from execution did not deter her from spending her imprisonment embroidering vestments and altar hangings and smuggling them out to her friends. ${ }^{78}$ While historians of the English mission have recognized that prisons became focal points for Catholic worship due to the relatively porous boundaries of English prisons and the numbers of priests incarcerated there during the late sixteenth and seventeenth centuries, less attention has been paid to their significance as centers for the production of contraband devotional materials. Gerard's memoir offers critical insight into this phenomenon, and how people found ways to express their defiance of the government's anti-Catholic policies even when confined by the state.

Gerard's autobiography also offers glimpses of how sacred materials influenced more pointed confrontations with the Elizabethan authorities. In a heated exchange with Richard Topcliffe, one of the government's more notorious interrogators who questioned Gerard under torture in 1594, Topcliffe brought out a copy of a papal bull and accused Gerard of coming into England to raise a rebellion

\footnotetext{
${ }^{76}$ Gerard, Autobiography, 117-29.

77 See Adam Hamilton, ed., The Chronicle of the English Augustinian Canonesses Regular of the Lateran at St. Monica's in Louvain (Now at St. Augustine's Priory, Newton Abbot, Devon, 1548 to 1625), 2 vols. (London: Sands \& Co., 1904), 1:82-84.

${ }^{78}$ Gerard, Autobiography, 52.
} 
against the queen. ${ }^{79}$ Gerard, "seeing the name of Jesus stamped at the top," kissed the paper in reverence, apparently shocking Topcliffe, who asked him why he would kiss the pope's bull. Gerard replied that he "kissed the name of Jesus to which all honor and love is due," and that if the paper was in fact an authentic papal bull, then he would kiss it on that account as well. At this, Gerard observed that Topcliffe flew into a rage, cursing and hurling insults at him. ${ }^{80}$ Gerard's account of his interactions with Topcliffe served a dual purpose in his narrative. He used the anecdote to demonstrate that he continued to show reverence to sacred materials even under duress, but in so doing he also illustrated how he managed to taunt his captors, by playing upon Topcliffe's revulsion of Catholic devotional practices and anxieties about the possible political motives of Catholic missionaries.

\section{Conclusion}

Surviving sources for the Jesuit mission to early modern England attest to the spiritual and political significance of sacred objects in English Catholic communities. From the start of the missions in 1580, priests produced and distributed sacred materials such as rosaries, grains of incense, the agnus dei, sacred pictures, relics, and holy water to the lay Catholics they ministered to, despite the dangers that they faced if caught. In many ways, the significance of sacred devotional materials in the English mission as conveyed through sources compiled by the Jesuits mirrors their importance in Jesuit missions to other parts of the early modern world. Their utility in inspiring conversions, their value among the laity as protective talismans, and the role they played in the martyrdoms of English Catholics all echo the uses to which sacred objects were put in other missionary contexts.

The parallels in the kinds of stories of sacred objects that appear in the annual letters and histories of the mission may have to do with the patterns that these writings tended to follow: the annual letters and official accounts of each Jesuit province were required to list notable conversions, the number of baptisms and reconciliations, and events of historical significance in the region. ${ }^{81}$ Even the political connotations that sacred objects acquired due to the hostility of Protestant rulers in early modern England bear similarities with the subversive meanings they acquired in other places, where ruling regimes were likewise suspicious or hostile toward Catholic missionaries. Harboring missionary priests and collecting relics at the executions of missionaries under the shogunate of Japan in the seventeenth century, for instance, were considered a direct assault on the shogun's authority in much the

\footnotetext{
${ }^{79}$ On Topcliffe, see Mark Rankin, "Richard Topcliffe and the Book Culture of the Elizabethan Catholic Underground," Renaissance Quarterly 72, no. 2 (2019): 492-536.

${ }^{80}$ Gerard, Autobiography, 95-96.

${ }^{81} \mathrm{McCoog}$, English and Welsh Jesuits, xxxi.
} 
same way that they signified challenges to the crown in post-Reformation England. ${ }^{82}$ The records of devotional materiality that appear in the sources for the English mission therefore serve as another example of how Catholics in early modern England fit within the global Catholic community that took shape in this period, one of many connections that historians have increasingly recognized. The scope of participation in this material culture, however, raises questions about the extent of political engagement among lay Catholics and missionaries in post-Reformation England, and the ways in which practices that have conventionally been described as fundamentally spiritual in nature can also be read as expressions of political dissent. The circulation of sacred materials therefore also compels us to re-evaluate the nature of the Jesuits' political involvement in post-Reformation England, and what exactly it meant for the Society's members to participate in political matters.

82 Üçerler, "Christian Missions in Japan," 331. 